\title{
Article \\ Impact of Geriatric Nutritional Risk Index and Modified Creatinine Index Combination on Mortality in Hemodialysis Patients
}

\author{
Hayato Fujioka $^{1}{ }^{(D)}$, Tsutomu Koike ${ }^{1}$, Teruhiko Imamura ${ }^{1, * \mathbb{D}}$, Fumihiro Tomoda ${ }^{2}$, Kota Kakeshita ${ }^{1}$, \\ Hidenori Yamazaki ${ }^{1}$ D and Koichiro Kinugawa $^{1}$
}

check for

updates

Citation: Fujioka, H.; Koike, T.;

Imamura, T.; Tomoda, F.; Kakeshita,

K.; Yamazaki, H.; Kinugawa, K.

Impact of Geriatric Nutritional Risk

Index and Modified Creatinine Index

Combination on Mortality in

Hemodialysis Patients. Nutrients

2022, 14, 801. https://doi.org/

$10.3390 /$ nu14040801

Academic Editor:

Vassilios Liakopoulos

Received: 20 January 2022

Accepted: 10 February 2022

Published: 14 February 2022

Publisher's Note: MDPI stays neutral with regard to jurisdictional claims in published maps and institutional affiliations.

Copyright: (C) 2022 by the authors. Licensee MDPI, Basel, Switzerland. This article is an open access article distributed under the terms and conditions of the Creative Commons Attribution (CC BY) license (https:// creativecommons.org/licenses/by/ $4.0 /)$
1 The Second Department of Internal Medicine, Toyama University, Toyama 930-0194, Japan; hfujioka@med.u-toyama.ac.jp (H.F.); tkoike@med.u-toyama.ac.jp (T.K.); kakeshit@med.u-toyama.ac.jp (K.K.) yamazaki@med.u-toyama.ac.jp (H.Y.); kinugawa@med.u-toyama.ac.jp (K.K.)

2 Faculty of Health Science, Fukui Health Science University, Fukui 910-3190, Japan; tomoda@fukui-hsu.ac.jp

* Correspondence: teimamu@med.u-toyama.ac.jp; Tel.: +81-76-434-2246

\begin{abstract}
The prognostic impact of the combination of a geriatric nutritional risk index (GRNI) and modified creatinine index, both of which assess nutritious status in hemodialysis patients, has not yet been well investigated thus far. Patients receiving maintenance hemodialysis in our institutes between February 2011 and January 2017 were retrospectively included. The baseline GRNI and modified Creatinine index were calculated and the impact of their combination on 5-year all-cause mortality following the index hemodialysis was investigated. A total of 183 patients (68.3 \pm 12.4 years, 98 men, hemodialysis duration $97 \pm 89$ months) were followed from the index hemodialysis for 5.5 years. Mean GNRI was 91.2 and mean modified Creatinine index was 22.2 in men and 19.6 in women. The 5-year survival was significantly stratified by the median values of GNRI and modified Creatinine index ( $p<0.05$ for both). Patients with low GNRI and a low modified Creatinine index had lower 5-year survival than those with the other three combination patterns $(p<0.05)$. A combination of GNRI and modified Creatinine index may be a promising tool to risk stratify mortality in dialysis patients.
\end{abstract}

Keywords: malnutrition; inflammation; end-stage renal disease

\section{Introduction}

Hemodialysis patients often have malnutrition and chronic inflammation, both of which synergistically progress end-organ dysfunction and atherosclerotic diseases [1,2]. This has recently been called malnutrition-inflammation-atherosclerosis syndrome. Of note, the unique malnutrition status in patients with hemodialysis, focusing on reduced dietary intake, chronic inflammation, resistance to anabolic hormones, loss of amino acids via dialysate, and muscle protein breakdown by hemodialysis, is called protein-energy wasting [3]. Protein-energy wasting is associated with mortality and morbidity as well as an impaired quality of life in hemodialysis patients [4-6].

Several indexes to assess protein-energy wasting, including geriatric nutritional risk index (GNRI) and modified creatinine (Cr) index, have been introduced [6-11]. GNRI is a simple tool for assessing nutritional status in various pathological conditions based on body mass index and serum albumin levels, focusing on visceral protein assessment [7]. Modified $\mathrm{Cr}$ index is a tool that reflects creatinine production, that is, skeletal muscle mass, focusing on the assessment of somatic protein [8]. Both have been independently shown to be associated with an increased risk for mortality and cardiovascular death in patients with hemodialysis. However, the prognostic impact of a combination of these two indexes remains uncertain. Given that the focuses of these indexes are independent (visceral protein status versus somatic protein status), we hypothesized that a combination of both indexes would have a further valuable prognostic impact on hemodialysis patients. 


\section{Materials and Methods}

\subsection{Patient Selection}

Consecutive patients who continued standard maintenance hemodialysis in our institute and associated dialysis centers between February 2011 and January 2017 were retrospectively included. None of them were on special diets. Patients aged under 20 years old or with missing data were excluded. The institutional ethical review board approved the study protocol. The informed consent was wavered given the retrospective nature of this study and the opt-out of this study protocol.

\subsection{Baseline Data Collection}

Baseline demographics, comorbidity, vital signs, medication data, and laboratory results were obtained from medical records. Comorbidity was also assessed using the Charlson risk index [12]. Blood urea nitrogen was measured before and after the index hemodialysis to determine Kt/V for urea, which was calculated using the Daugirdas method.

\subsection{Index Calculation}

GNRI was calculated using serum albumin level and body size as follows: $[14.89 \times$ serum albumin $(\mathrm{g} / \mathrm{dL})]+\{41.7 \times$ [current body weight $(\mathrm{kg}) /$ standard body weight $(\mathrm{kg})]\}$ [7]. Standard body weight was calculated as height $(\mathrm{m})^{2} \times 22$. If the current weight was greater than the standard weight, we set the ratio of current to standard weight $=1$.

Modified Cr index was calculated as follows: $16.21+1.12 \times(1$ if male; 0 if female $)-0.06$ $\times$ [age $($ years $)]-0.08 \times(\mathrm{Kt} / \mathrm{V}$ for urea $)+0.009 \times[$ serum $\mathrm{Cr}(\mu \mathrm{mol} / \mathrm{L})][8]$.

\subsection{Follow-Up}

All patients were followed from the index hemodialysis until the end of study period (January 2017). The primary outcome was all-cause mortality. The secondary outcome included death due to cardiovascular diseases (cardiac arrest, heart failure, coronary heart disease, aortic dissection and a cerebrovascular accident, including cerebral bleeding or infarction), infectious disease (respiratory, urinary tract, intestinal, cardiac, neurologic, soft tissue, septicemia, vascular access-related, and others), and cancer (solid and hematologic).

\subsection{Statistics}

Data are expressed as mean \pm standard deviation for continuous variables and the number and percentage for categorical variables. The patient cohort was stratified by the median levels of GNRI and modified $\mathrm{Cr}$ index, respectively. The freedom from the primary/secondary endpoints was stratified by the two indexes and compared using a logrank test. The time-to-event analysis was performed using Cox proportional hazard ratio regression analysis, which was adjusted for clinically significant variables including age, sex, dialysis vintage, diabetes mellitus, history of cardiovascular events, Charlson risk index, hemoglobin, phosphate, total cholesterol, C-reactive protein, and intact parathormone. Two-tailed $p<0.05$ was considered statistically significant. Analyses were performed using $\mathrm{R}$ software version 3.5.2 (R Foundation for Statistical Computing, Vienna, Austria).

\section{Results}

\subsection{Baseline Characteristics}

A total of 193 patients were considered for inclusion in this study. Of them, 10 were excluded due to missing data. Finally, 183 patients $(68.3 \pm 12.4$ years, 98 men, hemodialysis duration $97 \pm 89$ months) were included (Table 1). Mean GNRI was $91.2 \pm 10.9$. Mean modified $\mathrm{Cr}$ index was $22.2 \pm 2.5$ in males and $19.6 \pm 2.2$ in females, respectively. The causes of end-stage renal disease were as followed; 51 chronic glomerulonephritis, 76 diabetic nephropathy, 18 nephrosclerosis, 16 polycystic kidney disease, and 22 others. 
Table 1. Baseline characteristics.

\begin{tabular}{|c|c|}
\hline & $N=183$ \\
\hline \multicolumn{2}{|l|}{ Demographics } \\
\hline Males, $n(\%)$ & $98(53.6)$ \\
\hline Age, years & $68.3 \pm 12.4$ \\
\hline Dialysis vintage, month & $97 \pm 89$ \\
\hline Systolic blood pressure, $\mathrm{mmHg}$ & $150 \pm 25$ \\
\hline \multicolumn{2}{|l|}{ Comorbidity } \\
\hline Presence of diabetes, $n(\%)$ & $76(41)$ \\
\hline History of cardiovascular events, $n(\%)$ & $51(27)$ \\
\hline Charlson risk index & $3.5 \pm 1.3$ \\
\hline \multicolumn{2}{|l|}{ Cause of end-stage renal disease } \\
\hline Diabetic nephropathy, $n(\%)$ & $74(40.4)$ \\
\hline Chronic glomerulonephritis, $n(\%)$ & $48(26.2)$ \\
\hline Glomerulosclerosis, $n(\%)$ & $48(26.2)$ \\
\hline Polycystic disease, $n(\%)$ & $16(8.7)$ \\
\hline Others, $n(\%)$ & $16(8.7)$ \\
\hline \multicolumn{2}{|l|}{ Laboratory data } \\
\hline Hemoglobin, g/dL & $10.0 \pm 1.2$ \\
\hline Serum albumin, $\mathrm{g} / \mathrm{dL}$ & $3.4 \pm 0.4$ \\
\hline Serum urea nitrogen, $\mathrm{mg} / \mathrm{dL}$ & $60.4 \pm 14.5$ \\
\hline Serum creatinine, $\mathrm{mg} / \mathrm{dL}$ & $10.6 \pm 2.6$ \\
\hline Serum uric acid, mg/dL & $7.6 \pm 1.2$ \\
\hline Corrected serum calcium, mg/dL & $9.3 \pm 0.7$ \\
\hline Serum phosphate, $\mathrm{mg} / \mathrm{dL}$ & $5.0 \pm 1.2$ \\
\hline Serum C-reactive protein, $\mathrm{mg} / \mathrm{dL}$ & $0.4 \pm 0.7$ \\
\hline Serum total cholesterol, mg/dL & $148 \pm 29$ \\
\hline Serum triglycerides, $\mathrm{mg} / \mathrm{dL}$ & $109 \pm 53$ \\
\hline Intact parathormone, $\mathrm{pg} / \mathrm{mL}$ & $155 \pm 167$ \\
\hline $\mathrm{Kt} / \mathrm{V}$ ratio for urea & $1.43 \pm 0.28$ \\
\hline \multicolumn{2}{|l|}{ Index } \\
\hline GNRI & $91.2 \pm 10.9$ \\
\hline Modified Cr index (male), $\mathrm{mg} / \mathrm{kg} /$ day & $22.2 \pm 2.5$ \\
\hline Modified $\mathrm{Cr}$ index (female), $\mathrm{mg} / \mathrm{kg} /$ day & $19.6 \pm 2.2$ \\
\hline \multicolumn{2}{|l|}{ Medication } \\
\hline Angiotensin receptor blocker, $n(\%)$ & $81(48)$ \\
\hline Calcium channel blocker, $n(\%)$ & $101(60)$ \\
\hline Beta-blocker, $n(\%)$ & $34(20)$ \\
\hline Statin, $n(\%)$ & $25(15)$ \\
\hline Anti-platelets, $n(\%)$ & $82(49)$ \\
\hline
\end{tabular}

$\mathrm{Cr}$, creatinine; GNRI, geriatric nutritional risk index.

\subsection{Clinical Outcomes}

During a mean follow-up period of 5.5 years, there were 70 deaths ( 28 cardiovascular diseases, 21 infectious diseases, 11 cancer, and 10 others).

\subsection{Stratification of Clinical Outcomes by GNRI}

Patients were divided into two groups based on the median GNRI, namely the higher group (GNRI $\geq 91.6, n=93$ ) and the lower group (GNRI $<91.6, n=90)$. The five-year survival was significantly lower in the lower GNRI group ( $45 \%$ versus $76 \%, p<0.001$; Figure 1A). The lower GNRI group was associated with the incidence of primary endpoint in all three multivariate models including potential confounders ( $p<0.05$ for all; Table 2).

Freedom from death due to cardiovascular and infectious diseases was also significantly stratified by the GNRI levels, respectively ( $p<0.05$ for both), whereas those of malignant disease were not statistically different $(p=0.70)$. 
(A) All-cause death mortality across median categories of GNRI

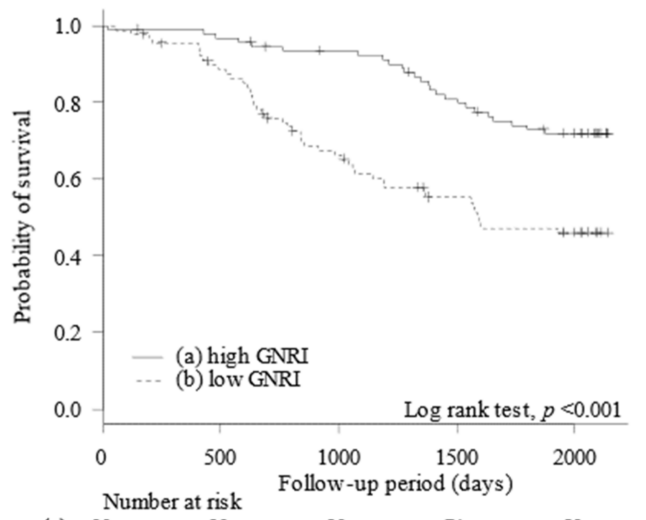

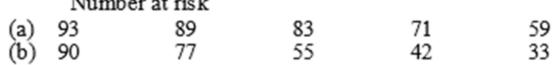

(B) All-cause death mortality across median categories of modified

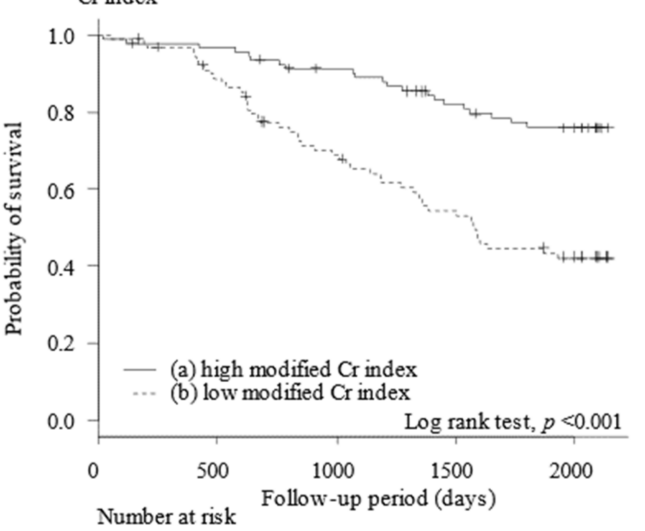

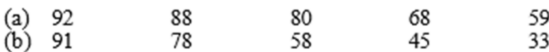

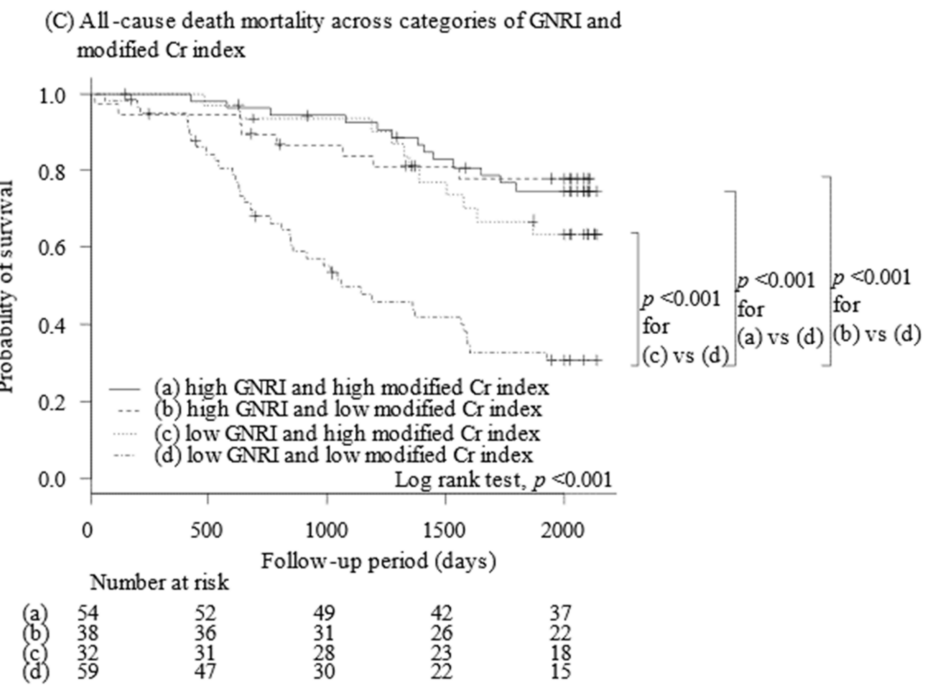

Figure 1. Five-year survival stratified by GNRI (A), modified $\mathrm{Cr}$ index (B), and a combination of both (C). Cr, creatinine; GNRI, geriatric nutritional risk index.

Table 2. Prognostic impacts of each index.

\begin{tabular}{|c|c|c|c|c|c|c|c|c|}
\hline & \multicolumn{2}{|c|}{ Unadjusted Model } & \multicolumn{2}{|c|}{ Multivariable Model 1} & \multicolumn{2}{|c|}{ Multivariable Model 2} & \multicolumn{2}{|c|}{ Multivariable Model 3} \\
\hline & $\begin{array}{c}\text { Hazard Ratio } \\
(95 \% \text { CI })\end{array}$ & $p$-Value & $\begin{array}{c}\text { Hazard Ratio } \\
(95 \% \text { CI })\end{array}$ & $p$-Value & $\begin{array}{c}\text { Hazard Ratio } \\
(95 \% \text { CI })\end{array}$ & $p$-Value & $\begin{array}{c}\text { Hazard Ratio } \\
(95 \% \text { CI })\end{array}$ & $p$-Value \\
\hline \multicolumn{9}{|l|}{ GNRI } \\
\hline High GNRI & $\begin{array}{c}1.00 \\
\text { (reference) }\end{array}$ & - & $\begin{array}{c}1.00 \\
\text { (reference) }\end{array}$ & - & $\begin{array}{c}1.00 \\
\text { (reference) }\end{array}$ & - & $\begin{array}{c}1.00 \\
\text { (reference) }\end{array}$ & - \\
\hline Low GNRI & $\begin{array}{c}2.59 \\
(1.59-4.23)\end{array}$ & $<0.001$ & $\begin{array}{c}2.18 \\
(1.31-3.64)\end{array}$ & $<0.01$ & $\begin{array}{c}2.19 \\
(1.29-3.73)\end{array}$ & $<0.01$ & $\begin{array}{c}2.05 \\
(1.17-3.60)\end{array}$ & $<0.05$ \\
\hline \multicolumn{9}{|l|}{ Modified Cr index } \\
\hline High modified $\mathrm{Cr}$ index & $\begin{array}{c}1.00 \\
\text { (reference) }\end{array}$ & - & $\begin{array}{c}1.00 \\
\text { (reference) }\end{array}$ & - & $\begin{array}{c}1.00 \\
\text { (reference) }\end{array}$ & - & $\begin{array}{c}1.00 \\
\text { (reference) }\end{array}$ & - \\
\hline Low modified Cr index & $\begin{array}{c}3.15 \\
(1.89-5.26)\end{array}$ & $<0.001$ & $\begin{array}{c}2.02 \\
(1.11-3.68)\end{array}$ & $<0.05$ & $\begin{array}{c}1.81 \\
(0.97-3.35)\end{array}$ & 0.06 & $\begin{array}{c}1.82 \\
(0.94-3.50)\end{array}$ & 0.07 \\
\hline
\end{tabular}

Unadjusted and multivariable-adjusted HRs were analyzed by the Cox proportional hazards risk model with all-cause death. Multivariable-adjusted model 1 was adjusted for age and sex. Model 2 was adjusted for age, sex, dialysis vintage, the presence of diabetes and history of cardiovascular events. Model 3 was adjusted for age, sex, dialysis vintage, hemoglobin, $\log _{10} \mathrm{C}$-reactive protein, phosphate, total cholesterol, intact parathormone, the presence of diabetes, history of cardiovascular events and Charlson risk index. A two-tailed $p$-value $<0.05$ was considered statistically significant. High GNRI means GNRI $\geq 91.6$. High $\mathrm{Cr}$ index means $\mathrm{Cr}$ index $\geq 22.3$ for males or $\geq 19.9$ for females. CI, confidence interval; $C r$, creatinine; GNRI, geriatric nutritional risk index. 


\subsection{Stratification of Clinical Outcomes by Modified Cr Index}

Patients were also divided into two groups based on the median modified $\mathrm{Cr}$ index of each gender, i.e., the higher group (modified $\mathrm{Cr}$ index $\geq 22.3$ in male or $\geq 19.9$ in female, $n=92$ ) and the lower group (modified $\mathrm{Cr}$ index $<22.3$ in men or $<19.9$ in female, $n=91$ ). The lower $\mathrm{Cr}$ index group had significantly lower 5 -year survival ( $45 \%$ versus $76 \%, p<0.001$; Figure $1 \mathrm{~B}$ ). The modified $\mathrm{Cr}$ index was associated with the incidence of primary endpoint only in model 1 $(p<0.05$; Table 2).

The modified $\mathrm{Cr}$ index stratified the incidence of cardiovascular death and infection, respectively ( $p<0.05$ for both), whereas mortality due to malignancy was not stratified by modified Cr index $(p=0.33)$.

\subsection{Stratification of Clinical Outcomes by Both Indexes}

Fifty-nine patients had low GNRI and low modified Cr index, and 54 had high GNRI and high modified $\mathrm{Cr}$ index. Other 70 patients had either low GNRI or low modified $\mathrm{Cr}$ index (Table 3).

Table 3. Number of patients who were assigned to high/low indexes.

\begin{tabular}{cccc}
\hline & Men & Women & Total \\
\hline High GNRI and high modified Cr index, $n(\%)$ & $32(32.7)$ & $22(25.9)$ & $54(29.5)$ \\
High GNRI and low modified Cr index, $n(\%)$ & $24(24.5)$ & $14(16.5)$ & $38(20.8)$ \\
Low GNRI and high modified Cr index, $n(\%)$ & $16(16.3)$ & $16(18.8)$ & $32(17.5)$ \\
Low GNRI and low modified Cr index, $n(\%)$ & $26(26.5)$ & $33(38.8)$ & $59(32.2)$ \\
\hline
\end{tabular}

High GNRI means GNRI $\geq 91.6$. High Cr index means $\mathrm{Cr}$ index $\geq 22.3$ for males or $\geq 19.9$ for females. Cr, creatinine GNRI, geriatric nutritional risk index.

A combination of low GNRI and low modified $\mathrm{Cr}$ index was associated with a lower 5 -year survival compared with the other three combination patterns $(32 \%, p<0.001$ for all; Figure 1C). Among the other three combination patterns, 5 -year survivals were statistically not different $(p>0.05$ for all). Similar trends were observed in cardiovascular death and infection death (Figure 2A,B) but not in cancer death ( $p=0.22$; Figure 2C). Cox proportional hazard ratio regression analyses showed trends similar to the findings of log-rank test (Table 4).

Table 4. Prognostic impacts of combination of both indexes.

\begin{tabular}{|c|c|c|c|c|c|c|c|c|}
\hline & \multicolumn{2}{|c|}{ Unadjusted Model } & \multicolumn{2}{|c|}{ Multivariable Model 1} & \multicolumn{2}{|c|}{ Multivariable Model 2} & \multicolumn{2}{|c|}{ Multivariable Model 3} \\
\hline & $\begin{array}{l}\text { Hazard } \\
\text { Ratio } \\
(95 \% \text { CI })\end{array}$ & $p$-Value & $\begin{array}{l}\text { Hazard } \\
\text { Ratio } \\
(95 \% \text { CI })\end{array}$ & $p$-Value & $\begin{array}{l}\text { Hazard } \\
\text { Ratio } \\
(95 \% \text { CI })\end{array}$ & $p$-Value & $\begin{array}{l}\text { Hazard } \\
\text { Ratio } \\
(95 \% \text { CI })\end{array}$ & $p$-Value \\
\hline All-cause death & & & & & & & & \\
\hline $\begin{array}{l}\text { High GNRI and high } \\
\text { modified Cr index }\end{array}$ & $\begin{array}{c}1.00 \\
\text { (reference) }\end{array}$ & - & $\begin{array}{c}1.00 \\
\text { (reference) }\end{array}$ & - & $\begin{array}{c}1.00 \\
\text { (reference) }\end{array}$ & - & $\begin{array}{c}1.00 \\
\text { (reference) }\end{array}$ & - \\
\hline $\begin{array}{l}\text { High GNRI and low modified } \\
\text { Cr index }\end{array}$ & $\begin{array}{c}1.48 \\
(0.66-3.29)\end{array}$ & 0.34 & $\begin{array}{c}0.92 \\
(0.40-2.11)\end{array}$ & 0.84 & $\begin{array}{c}0.73 \\
(0.31-1.78)\end{array}$ & 0.62 & $\begin{array}{c}0.69 \\
(0.27-1.71)\end{array}$ & 0.42 \\
\hline $\begin{array}{l}\text { Low GNRI and high } \\
\text { modified Cr index }\end{array}$ & $\begin{array}{c}1.04 \\
(0.42-2.55)\end{array}$ & 0.93 & $\begin{array}{c}1.11 \\
(0.45-2.72)\end{array}$ & 0.83 & $\begin{array}{c}1.06 \\
(0.43-2.61)\end{array}$ & 0.9 & $\begin{array}{c}0.75 \\
(0.29-1.93)\end{array}$ & 0.55 \\
\hline $\begin{array}{l}\text { Low GNRI and low modified } \\
\text { Cr index } \\
\text { Cardiovascular death }\end{array}$ & $\begin{array}{c}4.60 \\
(2.52-8.39)\end{array}$ & $<0.001$ & $\begin{array}{c}2.83 \\
(1.41-5.69)\end{array}$ & $<0.01$ & $\begin{array}{c}2.54 \\
(1.24-5.21)\end{array}$ & $<0.05$ & $\begin{array}{c}2.33 \\
(1.06-5.13)\end{array}$ & $<0.05$ \\
\hline $\begin{array}{l}\text { High GNRI and high } \\
\text { modified Cr index }\end{array}$ & $\begin{array}{c}1.00 \\
\text { (reference) }\end{array}$ & - & $\begin{array}{c}1.00 \\
\text { (reference) }\end{array}$ & - & $\begin{array}{c}1.00 \\
\text { (reference) }\end{array}$ & - & $\begin{array}{c}1.00 \\
\text { (reference) }\end{array}$ & - \\
\hline $\begin{array}{l}\text { High GNRI and low modified } \\
\text { Cr index }\end{array}$ & $\begin{array}{c}1.54 \\
(0.45-5.32)\end{array}$ & 0.50 & $\begin{array}{c}1.43 \\
(0.41-4.94)\end{array}$ & 0.57 & $\begin{array}{c}1.41 \\
(0.41-4.91)\end{array}$ & 0.59 & $\begin{array}{c}1.49 \\
(0.41-5.39)\end{array}$ & 0.54 \\
\hline $\begin{array}{l}\text { Low GNRI and high } \\
\text { modified Cr index }\end{array}$ & $\begin{array}{c}1.07 \\
(0.26-4.49)\end{array}$ & 0.92 & $\begin{array}{c}0.87 \\
(0.20-3.86)\end{array}$ & 0.86 & $\begin{array}{c}0.69 \\
(0.15-3.14)\end{array}$ & 0.63 & $\begin{array}{c}0.69 \\
(0.14-3.37)\end{array}$ & 0.65 \\
\hline $\begin{array}{l}\text { Low GNRI and low modified } \\
\text { Cr index } \\
\text { Infection-associated death }\end{array}$ & $\begin{array}{c}4.30 \\
(1.55-11.9)\end{array}$ & $<0.01$ & $\begin{array}{c}3.46 \\
(1.07-11.1)\end{array}$ & $<0.05$ & $\begin{array}{c}3.08 \\
(0.91-10.4)\end{array}$ & 0.07 & $\begin{array}{c}3.14 \\
(0.89-11.0)\end{array}$ & 0.07 \\
\hline $\begin{array}{l}\text { High GNRI and high } \\
\text { modified Cr index }\end{array}$ & $\begin{array}{c}1.00 \\
\text { (reference) }\end{array}$ & - & $\begin{array}{c}1.00 \\
\text { (reference) }\end{array}$ & - & $\begin{array}{c}1.00 \\
\text { (reference) }\end{array}$ & - & $\begin{array}{c}1.00 \\
\text { (reference) }\end{array}$ & - \\
\hline
\end{tabular}


Table 4. Cont.

\begin{tabular}{|c|c|c|c|c|c|c|c|c|}
\hline & \multicolumn{2}{|c|}{ Unadjusted Model } & \multicolumn{2}{|c|}{ Multivariable Model 1} & \multicolumn{2}{|c|}{ Multivariable Model 2} & \multicolumn{2}{|c|}{ Multivariable Model 3} \\
\hline & $\begin{array}{c}\text { Hazard } \\
\text { Ratio } \\
(95 \% \text { CI })\end{array}$ & $p$-Value & $\begin{array}{c}\text { Hazard } \\
\text { Ratio } \\
(95 \% \text { CI })\end{array}$ & $p$-Value & $\begin{array}{l}\text { Hazard } \\
\text { Ratio } \\
(95 \% \text { CI })\end{array}$ & $p$-Value & $\begin{array}{c}\text { Hazard } \\
\text { Ratio } \\
(95 \% \text { CI })\end{array}$ & $p$-Value \\
\hline $\begin{array}{l}\text { High GNRI and low modified } \\
\text { Cr index }\end{array}$ & $\begin{array}{c}0.31 \\
(0.04-2.69)\end{array}$ & 0.29 & $\begin{array}{c}0.28 \\
(0.03-2.42)\end{array}$ & 0.25 & $\begin{array}{c}0.25 \\
(0.03-2.13)\end{array}$ & 0.20 & $\begin{array}{c}0.21 \\
(0.02-2.01)\end{array}$ & 0.17 \\
\hline $\begin{array}{l}\text { Low GNRI and high } \\
\text { modified Cr index }\end{array}$ & $\begin{array}{c}1.08 \\
(0.26-4.52)\end{array}$ & 0.92 & $\begin{array}{c}0.80 \\
(0.18-3.59)\end{array}$ & 0.76 & $\begin{array}{c}0.70 \\
(0.15-3.28)\end{array}$ & 0.65 & $\begin{array}{c}1.35 \\
(0.24-7.73)\end{array}$ & 0.74 \\
\hline $\begin{array}{l}\text { Low GNRI and low modified } \\
\text { Cr index }\end{array}$ & $\begin{array}{c}3.95 \\
(1.38-11.3)\end{array}$ & $<0.05$ & $\begin{array}{c}3.23 \\
(0.98-10.7)\end{array}$ & 0.05 & $\begin{array}{c}2.99 \\
(0.89-9.98)\end{array}$ & 0.08 & $\begin{array}{c}8.45 \\
(1.80-39.7)\end{array}$ & $<0.01$ \\
\hline
\end{tabular}

Unadjusted and multivariable-adjusted HRs were analyzed by the Cox proportional hazards risk model with all-cause death. Multivariable-adjusted model 1 was adjusted for age and sex. Model 2 was adjusted for age, sex dialysis vintage, the presence of diabetes and history of cardiovascular events. Model 3 was adjusted for age, sex, dialysis vintage, hemoglobin, $\log _{10} \mathrm{C}$-reactive protein, phosphate, total cholesterol, intact parathormone, the presence of diabetes, history of cardiovascular events and Charlson risk index. A two-tailed $p$-value $<0.05$ was considered statistically significant. High GNRI means GNRI $\geq 91.6$. High $\mathrm{Cr}$ index means $\mathrm{Cr}$ index $\geq 22.3$ for males or $\geq 19.9$ for females. Cr, creatinine; GNRI, geriatric nutritional risk index.
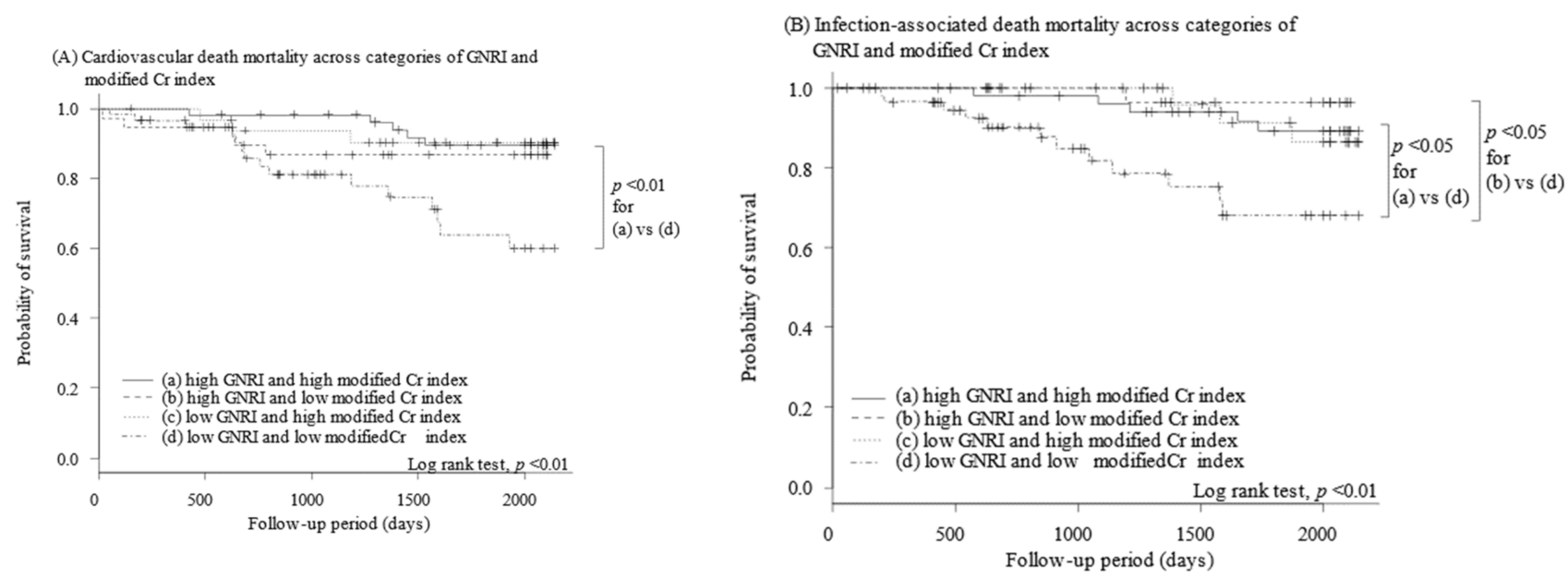

(C) Malignancy -associated death mortality across categories of GNRI and modified $\mathrm{Cr}$ index

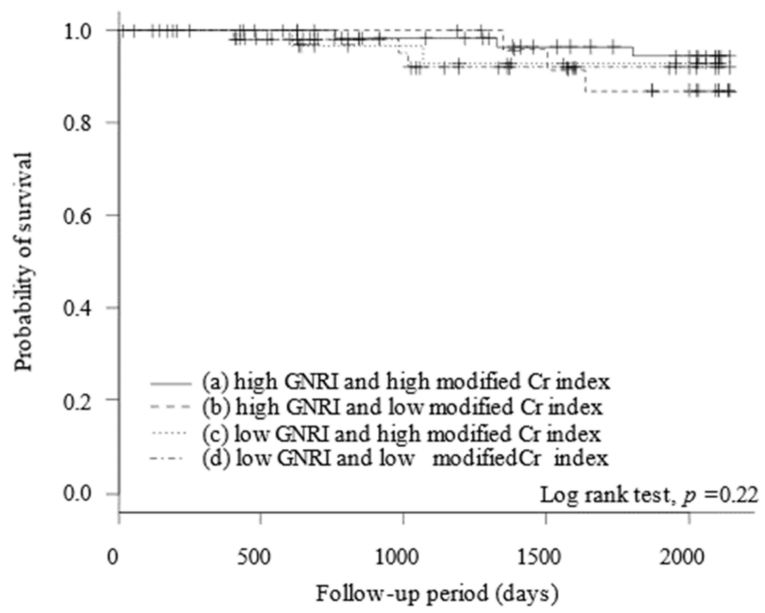

Figure 2. Five-year freedom free from cardiovascular death (A), infection death (B), and cancer death $(\mathbf{C})$ stratified by a combination of GNRI and modified $\mathrm{Cr}$ index. $\mathrm{Cr}$, creatinine; GNRI, geriatric nutritional risk index.

\section{Discussion}

In this study, we investigated, for the first time, the impact of a combination of two major malnutrition indexes, GNRI and modified $\mathrm{Cr}$ index on mortality in patients receiving 
maintenance hemodialysis. The 5-year survival was significantly stratified by the median values of GNRI and modified Cr index, respectively. Fifty-nine patients had low GNRI and a low modified $\mathrm{Cr}$ index, whereas 70 had either of them. Patients with low GNRI and low modified $\mathrm{Cr}$ index had lower 5-year survival than those with the other three combination patterns.

\subsection{GNRI and Modified Cr Index}

Yamada and colleagues recently demonstrated, using the J-DOPPS registry data, that the ability to predict survival in hemodialysis patients was statistically comparable between GNRI and modified Cr index [13]. The association between the two indexes was discussed in this study. A worse GNRI was associated with low serum Cr level, which is a dominant component of the modified $\mathrm{Cr}$ index. On the contrary, a worse modified $\mathrm{Cr}$ index was associated with low serum albumin level, which is a dominant determinant of GNRI. Both indexes were equally associated with body mass index and normalized protein catabolic rate, both of which are reliable markers of nutritious status in patients receiving hemodialysis. Therefore, they concluded that both indexes assess, at least partially, a similar nutritious status. However, they did not investigate the prognostic impact of the combination of these two indexes.

We hypothesized that a combination of GNRI and modified $\mathrm{Cr}$ index can be used to predict the survival of hemodialysis patients. In our study, we observed that GNRI and modified $\mathrm{Cr}$ index were not completely parallel. Approximately $40 \%$ of the patients had either a low GNRI or low modified Cr index. GNRI and modified Cr index might assess different nutritious statuses (visceral nutrition versus somatic nutrition), which indicates the implication to assess both indexes independently.

\subsection{Prognostic Impact of Both Indexes}

A group of low GNRI and low modified $\mathrm{Cr}$ index had lower survival than the other three combination patterns. Interestingly, if either of them was high, survival was comparable to the group with a high GNRI and high modified Cr index. Although further studies are warranted, the intervention of either of indexes (not necessarily both) might improve survival in patients with hemodialysis.

Both indexes were associated with several causes of death. Tanaka and colleagues similarly demonstrated, using the Q-cohort, that low GNRI was associated with cardiovascular or infection death but not cancer death [14]. Another study found a similar trend in the modified $\mathrm{Cr}$ index [11].

A reduced score in GNRI and modified $\mathrm{Cr}$ index is associated with incremental mortality $[15,16]$. Although some small studies observed partial prognostic improvement by the nutritious supports [17-19], a methodology of how to improve nutritious status in patients with dialysis has not yet been established. The impact of rehabilitation on somatic nutrition also remains a future concern [20].

\subsection{Limitations}

Some limitations should be noted. First, due to the retrospective nature of our study, all measured or unmeasured confounders may not have been properly controlled. Second, this study consists of a small sample cohort. Third, the optimal cutoff of these indexes remains controversial. A recent study proposed a prognostic cutoff of GNRI as 92, which was approximately comparable to ours.

\section{Conclusions}

A combination of GNRI and modified $\mathrm{Cr}$ index may be a promising tool to risk-stratify mortality in patients with hemodialysis.

Author Contributions: Conceptualization, H.F., T.K. and F.T.; methodology, H.F. and T.K.; investigation, H.F., T.K., K.K. (Kota Kakeshita) and H.Y.; writing—original draft preparation, H.F.; writing- 
review and editing, T.K. and T.I.; supervision, K.K. (Koichiro Kinugawa); project administration, T.K. All authors have read and agreed to the published version of the manuscript.

Funding: This research received no external funding.

Institutional Review Board Statement: The study was conducted in accordance with the Declaration of Helsinki, and approved by the Institutional Review Board (or Ethics Committee) of University of Toyama (protocol code R2021120 and date of approval).

Informed Consent Statement: Patient consent was waived as all the participants' data were anonymized before access.

Data Availability Statement: The data used for analysis in the present study are available upon request to the corresponding author. The data are not publicly available because of privacy or ethical restrictions.

Acknowledgments: The following personnel (institutions) helped data collection in this study: Masaharu Urakaze (Kamiichi General Hospital); Daisuke Takabayashi and Tomohiko Taki (Saiseikai Takaoka Hospital); Hitoshi Hirata (Jonan Naika Clinic); Keiko Konishi (Seiwa Hospital); Kunio Nakamura (Nakamura Kinen Hospital); Kiyoshi Izumino (Fujikoshi Hospital); Kenji Hayashi (Motomachi Naika Clinic); Hidenori Sugawara (Yokota Memorial Hospital).

Conflicts of Interest: The authors declare no conflict of interest.

\section{References}

1. Stenvinkel, P.; Heimbürger, O.; Lindholm, B.; Kaysen, G.A.; Bergström, J. Are there two types of malnutrition in chronic renal failure? Evidence for relationships between malnutrition, inflammation and atherosclerosis (MIA syndrome). Nephrol. Dial. Transplant. 2000, 15, 953-960. [CrossRef] [PubMed]

2. Kalantar-Zadeh, K.; Kopple, J.D. Relative contributions of nutrition and inflammation to clinical outcome in dialysis patients. Am. J. Kidney Dis. 2001, 38, 1343-1350. [CrossRef] [PubMed]

3. Ikizler, T.A.; Cano, N.J.; Franch, H.; Fouque, D.; Himmelfarb, J.; Kalantar-Zadeh, K.; Kuhlmann, M.K.; Stenvinkel, P.; TerWee, P.; Teta, D.; et al. Prevention and treatment of protein energy wasting in chronic kidney disease patients: A consensus statement by the International Society of Renal Nutrition and Metabolism. Kidney Int. 2013, 84, 1096-1107. [CrossRef] [PubMed]

4. Segall, L.; Moscalu, M.; Hogaş, S.; Mititiuc, I.; Nistor, I.; Veisa, G.; Covic, A. Protein-energy wasting, as well as overweight and obesity, is a long-term risk factor for mortality in chronic hemodialysis patients. Int. Urol. Nephrol. 2014, 46, 615-621. [CrossRef] [PubMed]

5. Fouque, D.; Kalantar-Zadeh, K.; Kopple, J.; Cano, N.; Chauveau, P.; Cuppari, L.; Franch, H.; Guarnieri, G.; Ikizler, T.A.; Kaysen, G.; et al. A proposed nomenclature and diagnostic criteria for protein-energy wasting in acute and chronic kidney disease. Kidney Int. 2008, 73, 391-398. [CrossRef] [PubMed]

6. Obi, Y.; Qader, H.; Kovesdy, C.P.; Kalantar-Zadeh, K. Latest consensus and update on protein-energy wasting in chronic kidney disease. Curr. Opin. Clin. Nutr. Metab. Care 2015, 18, 254-262. [CrossRef] [PubMed]

7. Bouillanne, O.; Morineau, G.; Dupont, C.; Coulombel, I.; Vincent, J.-P.; Nicolis, I.; Benazeth, S.; Cynober, L.; Aussel, C. Geriatric Nutritional Risk Index: A new index for evaluating at-risk elderly medical patients. Am. J. Clin. Nutr. 2005, 82, 777-783. [CrossRef] [PubMed]

8. Canaud, B.; Granger Vallée, A.; Molinari, N.; Chenine, L.; Leray-Moragues, H.; Rodriguez, A.; Chalabi, L.; Morena, M.; Cristol, J.-P. Creatinine index as a surrogate of lean body mass derived from urea $\mathrm{Kt} / \mathrm{V}$, pre-dialysis serum levels and anthropometric characteristics of haemodialysis patients. PLOS ONE 2014, 9, e93286. [CrossRef] [PubMed]

9. Yamada, K.; Furuya, R.; Takita, T.; Maruyama, Y.; Yamaguchi, Y.; Ohkawa, S.; Kumagai, H. Simplified nutritional screening tools for patients on maintenance hemodialysis. Am. J. Clin. Nutr. 2008, 87, 106-113. [CrossRef] [PubMed]

10. Xiong, J.; Wang, M.; Zhang, Y.; Nie, L.; He, T.; Wang, Y.; Huang, Y.; Feng, B.; Zhang, J.; Zhao, J. Association of Geriatric Nutritional Risk Index with Mortality in Hemodialysis Patients: A Meta-Analysis of Cohort Studies. Kidney Blood Press Res. 2018, 43, 1878-1889. [CrossRef] [PubMed]

11. Arase, H.; Yamada, S.; Yotsueda, R.; Taniguchi, M.; Yoshida, H.; Tokumoto, M.; Nakano, T.; Tsuruya, K.; Kitazono, T. Modified creatinine index and risk for cardiovascular events and all-cause mortality in patients undergoing hemodialysis: The Q-Cohort study. Atherosclerosis 2018, 275, 115-123. [CrossRef]

12. Charlson, M.E.; Pompei, P.; Ales, K.L.; MacKenzie, C.R. A new method of classifying prognostic comorbidity in longitudinal studies: Development and validation. J. Chronic Dis. 1987, 40, 373-383. [CrossRef]

13. Yamada, S.; Yamamoto, S.; Fukuma, S.; Nakano, T.; Tsuruya, K.; Inaba, M. Geriatric Nutritional Risk Index (GNRI) and Creatinine Index Equally Predict the Risk of Mortality in Hemodialysis Patients: J-DOPPS. Sci. Rep. 2020, 10, 5756. [CrossRef]

14. Tanaka, A.; Inaguma, D.; Shinjo, H.; Murata, M.; Takeda, A. Relationship between mortality and Geriatric Nutritional Risk Index (GNRI) at the time of dialysis initiation: A prospective multicenter cohort study. Ren. Replace Ther. 2017, 3, 27. [CrossRef] 
15. Yajima, T.; Yajima, K.; Takahashi, H. Impact of Annual Change in Geriatric Nutritional Risk Index on Mortality in Patients Undergoing Hemodialysis. Nutrients 2020, 12, 3333. [CrossRef] [PubMed]

16. Harada, T.; Sorimachi, H.; Obokata, M.; Sunaga, H.; Ishida, H.; Ito, K.; Ogawa, T.; Ando, Y.; Kurabayashi, M.; Negishi, K. The relationship between antecedent creatinine decreases and outcomes in patients undergoing hemodialysis. Hemodial. Int. 2020, 24, 89-98. [CrossRef] [PubMed]

17. Lacson, E.; Wang, W.; Zebrowski, B.; Wingard, R.; Hakim, R.M. Outcomes associated with intradialytic oral nutritional supplements in patients undergoing maintenance hemodialysis: A quality improvement report. Am. J. Kidney Dis. 2012, 60, 591-600. [CrossRef] [PubMed]

18. Cheu, C.; Pearson, J.; Dahlerus, C.; Lantz, B.; Chowdhury, T.; Sauer, P.F.; Farrell, R.E.; Port, F.K.; Ramirez, S.P.B. Association between oral nutritional supplementation and clinical outcomes among patients with ESRD. Clin. J. Am. Soc. Nephrol. 2013, 8 , 100-107. [CrossRef] [PubMed]

19. Weiner, D.E.; Tighiouart, H.; Ladik, V.; Meyer, K.B.; Zager, P.G.; Johnson, D.S. Oral intradialytic nutritional supplement use and mortality in hemodialysis patients. Am. J. Kidney Dis. 2014, 63, 276-285. [CrossRef] [PubMed]

20. Endo, M.; Nakamura, Y.; Murakami, T.; Tsukahara, H.; Watanabe, Y.; Matsuoka, Y.; Ohsawa, I.; Gotoh, H.; Inagaki, T.; Oguchi, E. Rehabilitation improves prognosis and activities of daily living in hemodialysis patients with low activities of daily living. Phys. Ther. Res. 2017, 20, 9-15. [CrossRef] [PubMed] 